\title{
Commercial Consolidation Model Applied to Transport Infrastructure
}

\author{
Joaquim José Guilherme de Aragão \\ Universidade de Brasília, Brasil \\ Lílian dos Santos Fontes Pereira Bracarense \\ Universidade Federal do Tocantins \\ Yaeko Yamashita \\ Universidade de Brasília
}

\begin{abstract}
Since the 1990s, transport concessions, including public-private partnerships (PPPs), have been increasingly adopted by governments as an alternative for financing and operations in public investments, especially in transport infrastructure. The advantage pointed out by proponents of these models lies in merging the expertise and capital of the private sector to the public interest. Several arrangements are possible and have been employed in different cases. After the duration of the first PPP contracts in transportation, many authors have analyzed the success and failure factors of partnerships. The occurrence of failures in some stages of the process can greatly encumber the public administration, incurring losses to the fiscal responsibility of the competent bodies. This article aims to propose a new commercial consolidation model applied to transport infrastructure to ensure fiscal sustainability and overcome the weaknesses of current models. Initially, a systematic review of the literature covering studies on transport concessions between 1990 and 2015 is offered, where the different approaches between various countries are compared and the critical success factors indicated in the studies are identified. In the subsequent part of the paper, an approach for the commercial consolidation of the infrastructure concessions is presented, where the concessionary is paid following a finalistic performance model, which includes the overall fiscal balance of regional growth. Finally, the papers analyses the usefulness of the model in coping with the critical success factors explained before.
\end{abstract}

\section{INTRODUCTION}

From the 1990's decade onwards concessions have been widely used in a lot of countries, particularly regarding infrastructure projects. In general lines, concessions can be classified according to the venture's profitability. In the Brazilian legislation, "onerous concessions" are those in which the project's financial advantages are able to remunerate the concessionaries without needing public subsidies, but where the Public Administration receives a fee; "free concessions" are those whose recipes break even the investor, but do not entitle the Public Administration to a fee payment; finally, the "subsidized concessions" do not break even, but are effectuated for strategic reasons, whereby the private sector 
receives a compensation that complement or substitute fully the user fees in order to assure the break even (Machado,2005).

Since 2004, the Public-Private Partnerships contracts (PPPs) have been regulated through the Law n. 11079, foreseeing two modalities: the "sponsored concession", when user fees and compensations by the Public Administration are provided; and the "administrative concession", where the Public Administration alone ensures the breakeven of the private investment. These modalities complement the free and onerous concessions which are ruled by the Law $n^{\circ} 8.987 / 1995$.

However, PPPs should not be regarded as a purely financial solution, since the main objective of PPPs is to assure that the private sector delivers timeliness, cost efficiency and project quality (Azevedo, 2014). Where prudential safeguards are not included, and the project is decided solely for political reasons, a PPP may bring serious instability to public finances and taxpayers. On the other side, the need for public investments in infrastructure in Brazil is absolutely striking but should not happen at the expense of the fiscal equilibrium (Afonso and Biasoto, 2007).

When the concession period of the first contracts expires, it is expected that the experiences are assessed, allowing the analysis of achieved results, the fulfilment of the initial goals and the recognition of the critical factors that will have influenced positively or negatively the implementation of the contracts.

The present paper starts with a systematic review of several academic works regarding the main critical factors for the success of a transportation infrastructure concessions. Subsequently, an alternative model for the commercial consolidation of infrastructure investments is exposed, which ensures fiscal equilibrium of the public expenses and delivers a proper response to identified critical factors.

\section{ASSESMENT OF CONCESSION POLICIES FOR TRANSPORTATION INFRASTRUCTURE INVESTMENT}

A systematic literature review of the transportation infrastructure concession experiences may point out some research tendencies (Aragão et al., 2004): critical success factors for public-private partnerships have been a major theme, as it turned out in the analysis of 60 documents. Hereby, following aspects turned out to be most relevant: a) political environment; b) legal environment; c) general social and economic environment; d) technical capacitation; e) technical characteristics of projects; f) economic and financial characteristics of projects and its financial engineering; g) project and contract management; and $\mathrm{h}$ ) selection and contracting process.

More recently, Osei-Kyei and Chan (2015) made a vast review of studies published between 
1990 and 2013 with respect to critical factors for success in public-private partnerships, which was not restricted to the transportation field. A more systematic review applied to the transportation concession theme on the 1990-2015 period revealed 46 articles in 25 journals.

A great amount of publications brings up case studies of specific countries and regions. Most of them refer to European countries (14 papers). According to Azevedo (2014), Portugal, United Kingdom, Spain and Greece are the countries in Europe that have made most use of PPP's.. In the second place Latin America (6 papers) stands out, although only a few studies have reported on the Brazilian experience. A considerable number of articles (18 papers) refer to the general international, not country-specific experience.

Coming to the issue of the critical success factors for PPP Macário et al. (2015) highlight for the Portuguese experience following aspects: deficiencies in the contract preparation; lack of assessment tools for projects and of guidelines; poor transparency and political commitment; optimistic bias in demand forecasts; and political interference into the decision-making. Osei-Kyei and Chan (2015) highlight other factors, such as adequacy of risk allocation and sharing; regulatory structure; macroeconomic stability; as well the financial capacity of the private sector.

Another authors dedicated their studies to more specific subjects as risk allocation and sharing (Chung et al. 2010; Scandizzo and Ventura, 2010; Cruz and Marques, 2012; Neves, 1995 apud Aragão et al., 2007; Franco and Pamplona, 2008). With respect to the design of concession contracts, Bray and Mulley (2012) point out as critical success factors the contract context (i.e. the underlying legal framework); the contract content (scope of the service, risk allocation, performance indicators); legal security and quality of contract management. Other aspects referred in the literature are measures to deal with with information asymmetry, the existence or independent regulatory bodies (Macario et al. 2015; Guasch and Straub, 2009). With respect to the upmost critical issue of the financial results, the determination of fee prices and of their top limits and readjustment rules; as well the consideration of extraordinary revenues make up a great part of the publications (Rocha and Garcia, 2011; Sirtaine et al., 2005; Schwind, 2010).

The Table 1 resumes the most referred success factors, as listed by Osei-Kyei e Chan (2015), Macário et al. (2015) and 


\begin{tabular}{|c|c|c|}
\hline Topic & Critical Factor & Impact \\
\hline \multirow{2}{*}{$\begin{array}{l}\text { External } \\
\text { Factors }\end{array}$} & $\begin{array}{l}\text { Defined legal } \\
\text { framework }\end{array}$ & $\begin{array}{l}\text { Legal uncertainty and political instability on the sector } \\
\text { can impede the project execution from happening. }\end{array}$ \\
\hline & $\begin{array}{l}\text { Macroeconomic } \\
\text { and political } \\
\text { stability }\end{array}$ & $\begin{array}{l}\text { Reduces project risk and provides planning } \\
\text { robustness. }\end{array}$ \\
\hline \multirow{4}{*}{ Contract } & $\begin{array}{l}\text { Risks } \\
\text { identification }\end{array}$ & $\begin{array}{l}\text { The previous non identification of a risk can lead to } \\
\text { higher contract costs. }\end{array}$ \\
\hline & Risks allocation & $\begin{array}{l}\text { The risk must be separately allocated with better } \\
\text { management conditions or the costs will be increased } \\
\text { and/or service execution intercepted. }\end{array}$ \\
\hline & Demand forecast & $\begin{array}{l}\text { Super estimated demand to the contract may burden } \\
\text { the public sector that usually assumes demand risk. } \\
\text { Underestimaded demands may hide the contract } \\
\text { financial feasibility. }\end{array}$ \\
\hline & $\begin{array}{l}\text { Responsabilities } \\
\text { and roles } \\
\text { transparency } \\
\text { between parts }\end{array}$ & Can avoid conflicts and roles superposition. \\
\hline \multirow{2}{*}{$\begin{array}{l}\text { Regulatory } \\
\text { Structure }\end{array}$} & $\begin{array}{l}\text { Transparency and } \\
\text { information flow }\end{array}$ & $\begin{array}{l}\text { Necessary aspects for the contract compliance } \\
\text { assurance. }\end{array}$ \\
\hline & $\begin{array}{l}\text { Performance } \\
\text { indicators }\end{array}$ & $\begin{array}{l}\text { The contract monitoring and control require the } \\
\text { existance of measurable indicators alined to its } \\
\text { objectives. }\end{array}$ \\
\hline
\end{tabular}

Table 1 - Critical factors for transportation concession contract success

\section{THE COMERCIAL CONSOLIDATION MODEL}

\subsection{Conceptual Fundaments}

The conceptual basis or the proposed commercial consolidation model is Territorial Engineering, which, according to Aragão and Yamashita (2010), deals with the conception and execution of territorial programs: these are characterized by an integrated set of interventions aiming to dynamize strategic planning and making major public and private investment projects feasible. The work field of Territorial Engineering comprises the design of territorial programs accordingly to several established technical, political, legal and other requirements, the design and putting to work of a variety of management functions (technical management); political advocacy strategy (political management); financial and fiscal management; design of contract framework; legal reforms; and information and knowledge management.

The main idea of the territorial program is to attract and to execute a coordinated set of public and private investments that is able to push up economic growth and subsequently increase fiscal revenue in a determined territory. Typically, a Territorial Program should be constituted of a set of projects (Aragão and Yamashita (2010): 
- Main productive projects: these are directly responsible for the aggregation of economic value;

- Additional productive projects: these are a series of production projects or services related to the first ones, belonging to their respective supply and distribution chain;

- Integrative projects: these do not belong directly to production chains of the main and additional production projects, but aim to catalyze the value aggregation and general growing process, comprising entrepreneurship incentive, education, capacitation, health, habitation, cultural, sportive and leisure activities, security, social promotion and environmental management; and finally the

- Infrastructure projects: these comprehend not only transportation, logistics and other technical infrastructures, but also the spatial and environmental structure, which are an essential boundary condition for the desired economic effects.

\subsection{The Commercial Consolidation Programme}

The use of PPP contracts as defined above for transportation infrastructure investment is progressing quickly. For the respective decision-making, traditional economic-financial feasibility studies are mandatory, which compare the implementation, operation and maintained costs with the revenue, which is basically dependent on the foreseen transportation demand. If this turns out to be insufficient at acceptable fare price levels, public sector counterparts ensure the break-even condition. However, the demand in less dense but strategical growth frontiers is too low, and the level of counterpart payments may harm fiscal sustainability

In order to overcome this financial and fiscal difficult, the proposed model (Figure 1) starts from an association of the conceded infrastructure investment with other projects in its surroundings, which are accomplished within a separate concession contract that attracts the investors. The legal basis of this additional and complementary contract is the concession for the use of public realm bound to conditions such as: a) programmed increase of traffic demand; and b) the production of multiplied fiscal revenues from the activities attracted to the region in an amount that covers the costs of the Public Administration (counterpart payments, additional infrastructure investments, other administrative and public service expenses etc.).

The Figure 1 below shows up the contract structure and the resulting expected economic flows within the Consolidation Programme. The design process of such a territorial program is detailed by Aragão and Yamashita (2010); the fiscal analysis model is presented in Aragão et al. (manuscript), where production goals needed for accomplish fiscal sustainability targets and the subsequently necessary actions are explained. 


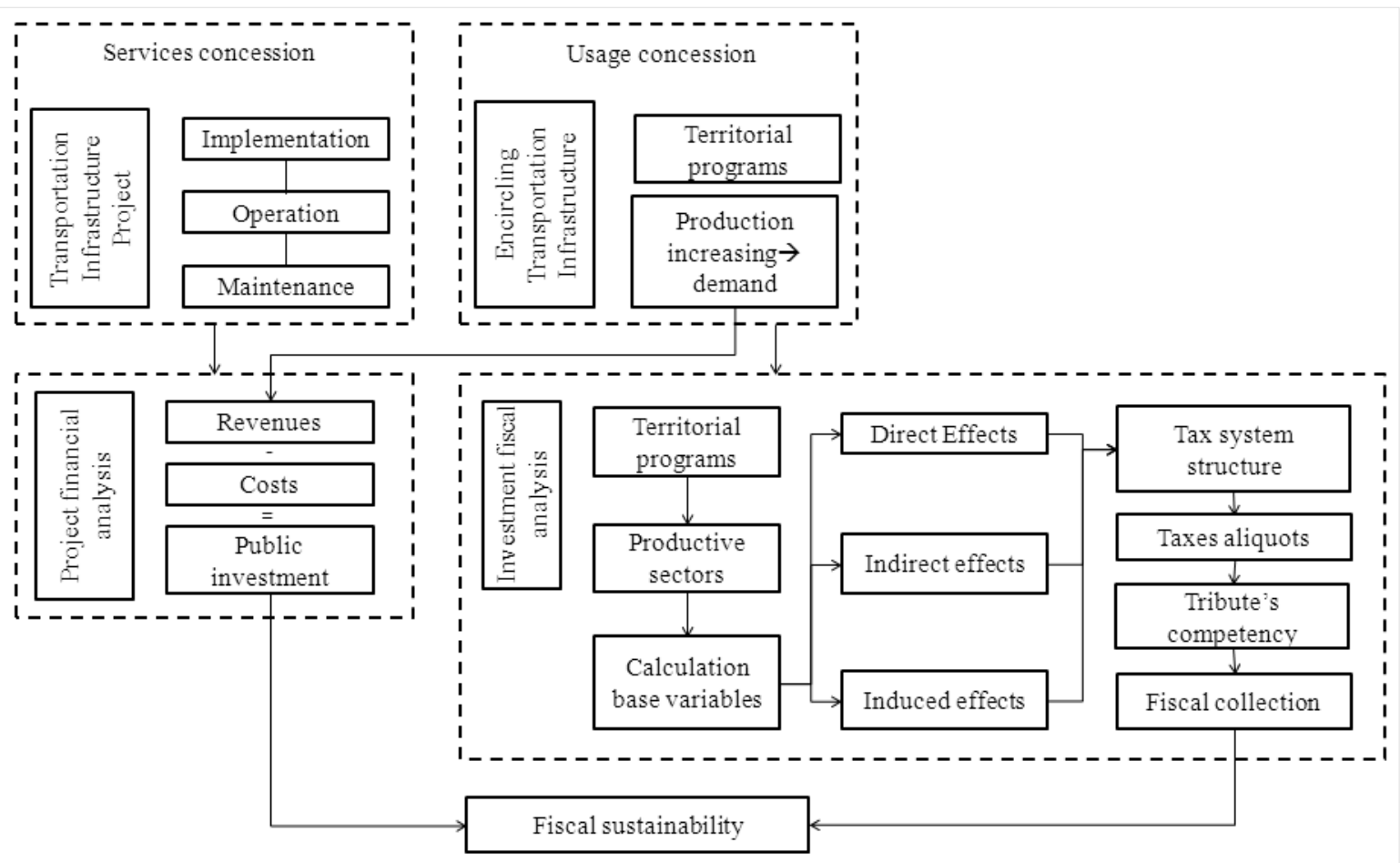

Figure 1 - Comercial consolidation model

\section{DISCUSSION}

When matched with the critical success factors for PPP contracts that have been considered in Section 2, the proposed model shows up a response capacity to each them, as shown in synthetically in the Table 2 .

\begin{tabular}{lll}
\hline Topic & Critical Factor & Response \\
\hline \multirow{3}{*}{$\begin{array}{l}\text { External } \\
\text { Factors }\end{array}$} & $\begin{array}{l}\text { Defined legal } \\
\text { framework }\end{array}$ & $\begin{array}{l}\text { The Territorial Engineering brings up a clear contract } \\
\text { framework which simplifies the responsibilities and } \\
\text { performance targets of each part. The private part is } \\
\text { free to choose the action and means to achieve the } \\
\text { targets. }\end{array}$ \\
\cline { 2 - 4 } & $\begin{array}{l}\text { Macroeconomic } \\
\text { and political } \\
\text { stability }\end{array}$ & $\begin{array}{l}\text { The territorial program is designed to ensure concrete } \\
\text { growth targets, which will ensure a positive } \\
\text { conjuncture for the regional economy. On the other } \\
\text { side, the political management process aims to ensure } \\
\text { political agreements between the involved actors, } \\
\text { minimizing the scenario of instability. }\end{array}$ \\
\hline \multirow{3}{*}{ Contract } & Risk management & $\begin{array}{l}\text { The risks are assigned more properly to the parts } \\
\text { which are able to cope with them. The concentration } \\
\text { of the duties of the concessionaire in economic } \\
\text { performance targets makes him free to choose the } \\
\text { proper means to cope with the risks. }\end{array}$ \\
\cline { 2 - 4 } & Demand forecast & $\begin{array}{l}\text { The demand is not considered as an independent } \\
\text { external factor, but as a direct contract target. The } \\
\text { proper business model, as delivered in the }\end{array}$ \\
\hline
\end{tabular}


procurement process by the winning bidder, shall demonstrate the feasibility to comply with the target. The measures taken to attract productive investment will be decided solely by the private partner, which will ensure enough competence for this task..

Responsibilities The fulfilment of the targets will be controlled and measures for together by the contractor and contracted parties and transparency be publicized.

\section{Table 2 - Responses of the proposed model to its critical factors}

\section{CONCLUSION}

The present paper starts from the discussion of the present practice of Private Public Partnerships (PPP) and of their critical success factors. It is shown that this practice implies many risks that are difficult to control and its inefficient assignment to the involved parties. Most of these risks are due to the facts that the economic, social and political environment remain outside of the action field of the parties. In order to ensure the break-even condition of the contracted party, the Public Administration assumes, on behalf of the taxpayer, the responsibility for events that are not to him to master, as economic growth, traffic demand of the infrastructure, and other aspects.

The Territorial Program approach devolves the competencies dependent on private investments and production of third parties that are at the origin of traffic generation and revenue sources to a third private party, which will be far more competent to ensure the needed results. These results are then contracted by government to the private sector, which will enjoy full freedom to decide on the strategy and means, provided that the rules of Law and of the public planning are complied with. As it is conclusively shown, this approach is able to deal better with the critical factors for the success of the partnership contracts.

\section{ACKNOLEDGEMENTS}

The authors thank CNPq and FAPDF for the financial support.

\section{REFERENCES}

AFONSO, J. R., BIASOTO JR. (2007): Investimento Público no Brasil: Diagnósticos e Proposições. Revista do BNDES. v. 14, n.27, pp. 71-122.

ARAGÃO, J. J. G. BRACARENSE, L. S. F. P. YAMASHITA, Y. BRANDÃO, R. (2016) Fiscal Feasibility Assessment Applied to Transport Infrastructure Projects. Proceedings $12^{\text {th }}$ Conference on Transport Engineering (CIT2016). Valencia, Spain. (in press)

ARAGÃO, J. J. G. YAMASHITA, Y. COSTA, J. O. E ALMEIDA, C. F. (2014) O esgotamento do modelo rodoviário e o papel potencial das hidrovias: Hidrovia Araguaia Tocantins. In: XXVIII ANPET - Congresso Nacional de Pesquisa e Ensino em Transporte, Curitiba. 
ARAGÃO, J. J. G., YAMASHITA, Y. (2010): Engenharia Territorial: Problemas e Territórios Programáticos. Texto de Discussão. Brasília: CEFTRU/UnB

ARAGÃO, J.; BRASILEIRO, A.; LIMA NETO, O.; MAIA, M. L.; MARAR, J. R.; ORRICO FILHO, R.; RODRIGUES, C. A. E SANTOS, E. (2004) Parcerias sociais para o desenvolvimento nacional e fatores críticos para o seu sucesso. Natal, RN: EDUFRN

AZEVEDO, S. (2014) PPP e o custo de um estado fraco: Toda a verdade sobre as parcerias público-privadas. Aletheia Editores, Lisboa, Portugal.

BRAY, D., MULLEY, C. (2013) Workshop 4: Designing contracts/concessions: What has worked and what has not and why? 12th International Conference Series on Competition and Ownership in Land Passenger Transport. Research in Transportation Economics. v. 39, p. 226-231.

CHUNG, D., HENSHER, D. A., ROSE, J. M. (2010) Toward the betterment of risk allocation: Investigating risk perceptions of Australian stakeholder groups to public privatepartnership toll road projects. Research in Transportation Economics. v. 30, p. 43-58.

CRUZ, C. O., MARQUES, R. C. (2012) Risk-Sharing in Seaport Terminal Concessions. Transport Reviews. v. 32, n. 4, pp.455- 471.

FRANCO, V. G. E PAMPLONA, J. B. (2008) Alocação de Riscos em Parcerias PúblicoPrivadas no Brasil. Revista Econômica do Nordeste, Fortaleza, v. 39, nº 1, pp. 25-45.

GUASCH, J. L. E STRAUB, S. (2009) Corruption and concession renegotiations. Evidence from the water and transport sectors in Latin America. Utilities Policy. v.17 pp. 185-190.

MACÁRIO, R., RIBEIRO, J., COSTA, J. D. (2015) Understanding pitfalls in the application of PPPs in transport infrastructure in Portugal. Transport Policy. V.41, p.90-99.

MACHADO, K. (2005) Concessões de rodovias: mito e realidade. 2 ed. São Paulo: Prêmio, 2005.

OSEI-KYEI, R. CHAN, A. P. C. (2015) Review of studies on the Critical Success Factors for Public-Private Partnership (PPP) projects from 1990 to 2013. International Journal of Project Management. v. 33 p.1335-1346.

SCANDIZZO, P. L., VENTURA, M. (2010) Sharing risk through concession contracts. European Journal of Operational Research. v. 207, p. 363-370.

SIRTAINE, S.; PINGLO, M. E.; GUASCH, J. L.; FOSTER, V. (2005) How profitable are infrastructure concessions in Latin America? Empirical evidence and regulatory implications. PPIAF trends and policy options ; no. 2. Washington, DC: World Bank.

SCHWIND, R. W. (2010) Remuneração do particular nas concessões e parcerias públicoprivadas. Dissertação de mestrado. Faculdade de Direito da Universidade de São Paulo 